\title{
Cloning and Characterization of an Esophageal-Gland-Specific Pectate Lyase from the Root-Knot Nematode Meloidogyne javanica
}

\author{
Elizabeth A. Doyle and Kris N. Lambert \\ Department of Crop Sciences, University of Illinois, Urbana 61801, U.S.A.
}

Submitted 10 December 2001. Accepted 25 February 2002.

\begin{abstract}
Root-knot nematodes (Meloidogyne javanica) are obligate sedentary endoparasites that must penetrate the host root to initiate their life cycle. Many enzymes are secreted by the nematode to facilitate host penetration; required enzymes may include pectate lyases and cellulases. Using differential screening, a class III pectate lyase, Mj-pel-1 (M. javanica pectate lyase 1), was cloned from a library enriched for esophageal gland genes. DNA gel blotting confirmed that the $\mathrm{Mj}$-pel-1 gene was of nematode origin and a member of a small multigene family. In situ hybridization localized the expression of $\mathrm{Mj}$-pel-1 to the basal cells of the esophageal glands, while immunolocalization detected the protein in the esophageal glands as well as on the exterior of the nematode, confirming that the protein is secreted. When MJ-PEL-1 was expressed in Pichia pastoris, the resulting protein was active. The pH optimum of MJ-PEL-1 was 10.0, and the enzyme was five times more active on pectate than on pectin. Like other class III pectate lyases, MJ-PEL-1 also displayed an absolute requirement for $\mathrm{Ca}^{2+}$. The rootknot nematode migrates through the middle lamella of the plant root; therefore, MJ-PEL-1 may be an important enzyme early in the infection process.
\end{abstract}

Additional keywords: parasitism, pathogen, and tomato.

Root-knot nematodes (Meloidogyne spp.) are obligate sedentary endoparasites of almost all cultivated plants (Sasser 1980). The second stage juvenile (J2) is the infectious stage of the root-knot nematode, moving through the soil and penetrating the host plant root in the zone of elongation. The $\mathrm{J} 2$ then migrates between the plant cells until it reaches the vascular tissue, where it injects secretions through its stylet into or around approximately six parenchyma cells. This causes the affected plant cells to undergo a dramatic transformation, becoming giant multinucleate cells on which the nematode nondestructively feeds throughout the rest of its life cycle (Williamson and Hussey 1996).

Secretions from esophageal glands may control essential processes of host penetration and giant cell formation. Rootknot nematodes have three esophageal glands-one dorsal and two subventral glands. Each gland is a single enlarged cell that is specialized to export secretions into the esophageal lumen of

Corresponding author: Kris N. Lambert, Email: knlamber@uiuc.edu

Nucleotide and amino acid sequence data reported are available in the GenBank database under accession number AF455757. the nematode and then out of the stylet. Early research showed that nematodes produced pectinases and cellulases that assist the nematode in penetrating the host root (Bird et al 1974; Dropkin 1963). More recent research has led to the identification in the subventral glands of a gene encoding a pectate lyase (Popeijus et al. 2000a) and several genes encoding cellulases (Smant et al. 1998). These proteins and other metabolites secreted by the glands are thought to be important for root penetration and feeding cell formation.

A growing body of evidence suggests that secretions from the esophageal glands play a role in nematode parasitism of plants (Ding et al. 1998; Lambert et al. 1999; Smant et al. 1998); therefore, the isolation and characterization of genes that code for gland-specific proteins is increasingly important. The number of esophageal gland genes that have been cloned is increasing (Gao et al. 2001; Popeijus et al. 2000a, 2000b; Wang et al. 2001). This list includes enzymes such as cellulases (Goellner et al. 2000; Rosso et al. 1999; Smant et al. 1998) and chorismate mutases (Lambert et al. 1999; Popeijus et al. 2000b). We currently are using a novel method to isolate nematode gland-specific genes (Lambert et al. 1999). A cDNA library was constructed from the esophageal gland region of Meloidogyne javanica and was differentially screened to identify genes expressed in the esophageal glands. One such gene encoded a pectate lyase (PL) (EC 4.2.2.2), a cell-wall-degrading enzyme.

Plant pathogens secrete a battery of pectinases, enzymes that are involved in the depolymerization of pectin. Pectin, a highly methylated form of pectate, is a major component of the plant primary cell wall and middle lamella. Among pectin-degrading enzymes, pectate lyases have been shown to be important virulence factors in bacterial (Barras et al. 1994) and fungal (Rogers et al. 2000) plant pathogens. Pectate lyases represent a diverse family of enzymes whose expression can be sensitive to a variety of environmental factors (Guo et al. 1996; HugouvieuxCotte-Pattat et al. 1996). The family of pectate lyases is diverse and can be divided into five classes. The classes are defined by homology to known pectate lyases. Some classes have been further characterized by tertiary structure of the protein sequence and by biochemical properties of the enzyme (Popeijus, et al. 2000a; Shevchik et al. 1997).

The pectin matrix of plants is found throughout the primary cell wall but is most concentrated in the middle lamella between cells (Barras et al. 1994). The root-knot nematode moves within plant roots by migrating between plant cells along the middle lamella; therefore, secreted pectinases may be essential for nematode penetration of the root. Here we report on the cloning and characterization of MJ-PEL-1, a class III pectate lyase from the root-knot nematode, $M$. javanica. 


\section{RESULTS}

Description and origin of the $M j$-pel-1 gene.

The $M j$-pel- 1 cDNA was cloned by differentially screening a library as previously described (Lambert et al. 1999). The $M j$ pel-l open reading frame is $813 \mathrm{bp}$ in length. The predicted protein is 271 amino acids (aa) long and appears to have a signal sequence 22 aa in length, resulting in a predicted mature protein of 249 aa in length or approximately $27 \mathrm{kDa}$. A motif search (Hofmann et al. 1999) identified two possible N-glycosylation sites at amino acids 9 and 161 (based on the 249-aa mature protein), indicating that MJ-PEL-1 could be a glycoprotein. MJ-PEL-1 is predicted to be extracellular by the subcellular-targeting prediction computer program PSORT (Nakai and Kanehisa 1992). The amino acid sequence of MJ-PEL-1 also was compared to other known pectate lyases. By homology, MJ-PEL-1 is most similar to the class III pectate lyases.

The Mj-pel-1 cDNA had homology to fungal and bacterial sequences; therefore, it was important to confirm that it was of nematode origin. The Mj-pel-1 cDNA was radiolabeled and hybridized to a DNA gel blot containing EcoRI- and EcoRVdigested DNA from $M$. javanica and tomato (Fig. 1). The $M j$ pel-1 cDNA hybridized strongly to three fragments in both the EcoRI and EcoRV digests of M. javanica DNA. These fragments ranged in size between 3.4 and $12 \mathrm{~kb}$. The Mj-pel-1 cDNA hybridized to multiple fragments and neither the cDNA nor the genomic clone contains EcoRI or EcoRV sites; there-

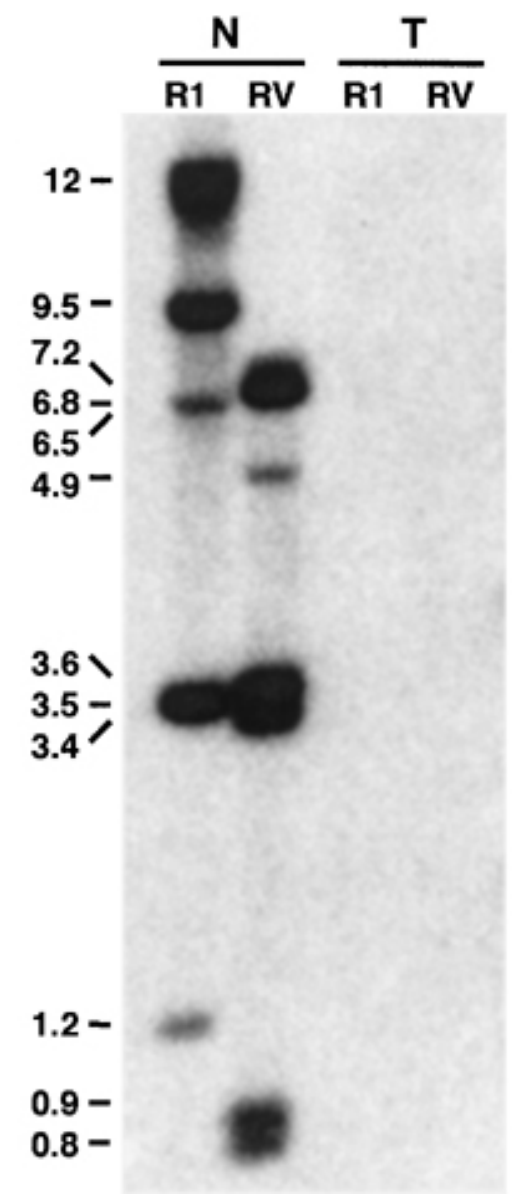

Fig. 1. Genomic DNA gel blot. N (nematode DNA) and T (tomato DNA) identify the DNA type in each lane of the blot. Nematode and tomato DNA were digested with EcoRI (RI) in the first lane of each pair and EcoRV (RV) in the second lane in each pair. The blot was hybridized with the Mj-pel-1 (Meloidogyne javanica Pectate Lyase 1) cDNA. Size of the hybridizing DNA fragments is given in kilobase pairs. fore, Mj-pel-1 is probably a member of a small, multigene family. No hybridization to tomato DNA was observed, indicating that $M j$-pel- 1 is of nematode origin.

\section{Pectate lyase diversity.}

The predicted protein sequence of MJ-PEL-1 was compared with the amino acid sequences of a variety of functional pectate lyases (Fig. 2). The MJ-PEL-1 sequence shows highest similarity with the class III pectate lyases of bacterial and fungal origin. Class III pectate lyases have four highly conserved regions (Shevchik et al. 1997) and are characterized by the presence of several cysteine residues (Popeijus et al. 2000a). The four conserved regions of class III pectate lyases are retained in MJ-PEL-1 (Fig. 2). MJ-PEL-1 has 12 cysteine residues as well as several charged residues potentially involved in catalysis (Popeijus et al. 2000a). The highly conserved, charged residues are indicated with an asterisk in Figure 2.

DNA gel blotting (Fig. 1) suggested that $M j$-pel- 1 is a member of a small gene family; therefore, nematode expressed sequence tag (EST) databases were searched for ESTs similar to Mj-pel-1 (McCarter et al. 2000a,b). Although 25 similar ESTs were identified in the database, none were identical or highly similar to $M j$-pel-1, indicating that $M j$-pel- 1 is a novel pectate lyase. Clones with significant similarity (TBLASTN, E-value 2e-05 or greater) were aligned with the Mj-pel-1 cDNA using CLUSTALW, version 1.8 (Jeanmougin et al. 1998). Three major contigs of ESTs were observed. With the inclusion of Pel-1 from Globodera rostochiensis, five overall groups of nematode pectate lyases were observed (Table 1). By homology, all five groups of pectate lyases were most similar to class III pectate lyases. The contigs of ESTs then were examined. $M$. incognita had two distinct contigs of pectate lyases; one contig was most similar to PelA from Fusarium solani f. sp. pisi, while the second contig was most similar to PelD from $F$. solani f. sp. pisi. Mj-pel-1 also was similar to Heterodera glycines ESTs; $14 \mathrm{H}$. glycines ESTs belonging to one contig were identified. The $H$. glycines ESTs were most similar to PelA from Bacillus spp.

The ESTs within each contig were examined to determine if they were identical. The two ESTs of the M. incognita-PelD contig were identical; however, the ESTs from $M$. incognitaPelA contig and the EST from the $H$. glycines contig appear to have more than one cDNA represented. It is difficult to say if there are multiple forms of pectate lyases in the contigs, because the quality of EST sequences makes it difficult to determine exactly how many genes are represented.

\section{Protein expression and characterization.}

To obtain protein for characterization, the Mj-pel-1 open reading frame was cloned into a Pichia pastoris expression vector. The construct was designed so that the resulting secreted protein product would be mature MJ-PEL-1 protein. MJ-PEL-1 expression was then induced under conditions favorable to pectate lyase activity. The protein was secreted in the Pichia culture supernatant and was $95 \%$ pure as expressed (Fig. 3). As a result, the protein was concentrated but not further purified prior to biochemical characterization.

To biochemically characterize a pectate lyase, the change in absorbance is determined with pectate (polygalacturonic acid) as a substrate. Release of unsaturated galacturonide product will result in a net increase in the absorbance at 232 (Guo et al. 1996). Using this assay, the enzymatic activity of recombinant MJ-PEL-1 was then characterized under various conditions. As outlined in Table 2, MJ-PEL-1 had pectate lyase activity. Like other class III pectate lyases, this activity has an absolute requirement for the addition of $\mathrm{Ca}^{2+}$ (Shevchik et al. 1997). Addition of EDTA to a final concentration of $1 \mathrm{mM}$ abolishes activity 
(Table 2); subsequent additional $\mathrm{Ca}^{2+}$ to a final concentration of $1.2 \mathrm{mM}$ restores pectate lyase activity. The cofactor requirements of MJ-PEL-1 were further explored to determine if other divalent metal ions could substitute for $\mathrm{Ca}^{2+}$. When MJ-PEL-1 was evaluated for activity in the presence of $\mathrm{Co}^{2+}, \mathrm{Mg}^{2+}, \mathrm{Mn}^{2+}$, and $\mathrm{Zn}^{2+}$, no pectate lyase activity was detected (Table 2). As negative controls, proteins secreted from the P. pastoris KM71 strain alone had no pectate lyase activity, and a Pichia line expressing bovine serum albumin (BSA) also had no pectate lyase activity. It also should be noted that, when protein expression was induced at $\mathrm{pH} 6.0$ according to the manufacturer's instructions, yield of MJ-PEL-1 was high but the protein was inactive.

To further characterize the pectate lyase activity of MJ-PEL-1, the optimal $\mathrm{pH}$ for activity was determined (Fig. 4). MJ-PEL-1 has increased activity at $\mathrm{pH} 8.0$ and above, with an optimal $\mathrm{pH}$ of 10.0. Activity was approximately fivefold greater on pectate than on pectin.

Multiple forms of MJ-PEL-1 were observed upon expression in P. pastoris and after deglycosylation (Fig. 3). The exact reason for the presence of multiple forms of the protein remains unclear. Potential explanations include incomplete processing of the signal peptide during secretion, variable levels of post-translational modification, or potential degradation in the Pichia culture supernatant.
MJ-PEL-1 is predicted to have two N-glycosylation sites, and the Pichia-expressed protein is larger than predicted when analyzed by sodium dodecyl sulfate-polyacrylamide gel electrophoresis (SDS-PAGE) (Fig. 3). Therefore, the recombinant protein was treated with PNGase F to determine whether the glycosylation sites were utilized in Pichia spp. Figure 3 demonstrates that the molecular weight of MJ-PEL-1 decreases following treatment with PNGase F. The observation that active MJ-PEL-1 protein is glycosylated when expressed in Pichia spp. suggests that the protein may be glycosylated when expressed in the nematode. $P$. pastoris is known to hyperglycosylate proteins (Romanos et al. 1992; Vozza et al. 1996); therefore, the degree of glycosylation may vary from that of the nematode.

\section{Tissue localization of $\mathrm{Mj}$-pel-1 mRNA.}

To determine which nematode organs express $M j$-pel-1, we performed in situ RNA hybridizations. When an $M j$-pel-1 antisense riboprobe was hybridized to paraffin sections of nematode-infected roots, the antisense $M j$-pel-1 probe specifically hybridized to a region in the nematode consistent in location with the basal cells of the esophageal glands (Fig. 5). Part of the anterior extension of the glands hybridized to the probe, confirming that the signals were from the gland cells. We

Region I

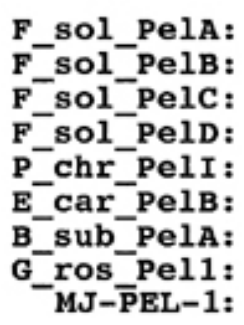

F_sol_PelA: F_sol_pelB: F_sol_PelC: F-sol-Peld: P_chr_pelI : E_car_PelB: B_sub_PelA: G_ros_Pel1: MJ-PEL-1:

F_sol_pelA:

F_sol_pelB:

F-sol-Pelc:

F-sol-peld:

P_chr_pelI :

E_car_pelB :

B_sub_PelA:

G_ros-Pel1:

MJ-PEL-1:

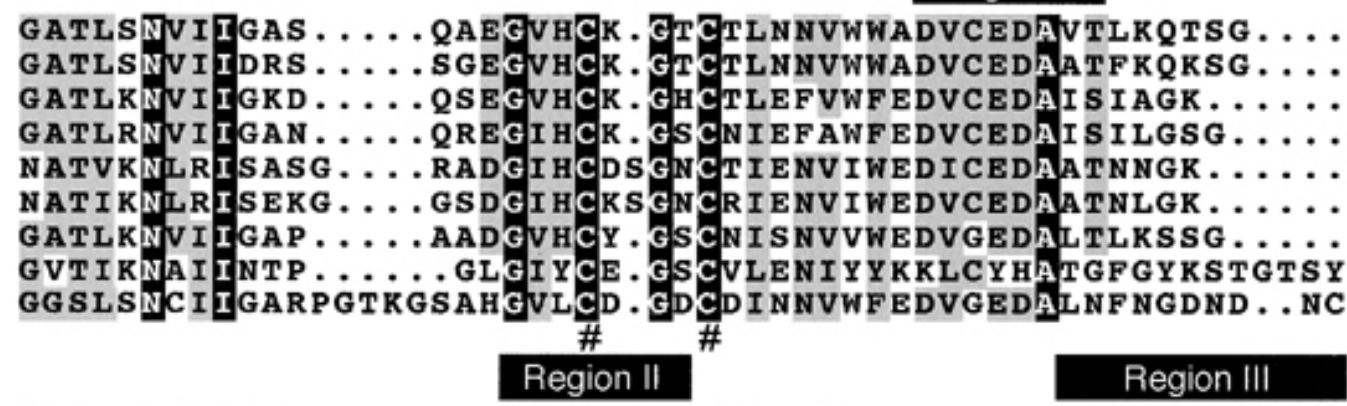

TSY INGGGAFHAS . . . . . DRI IQFNGRGTVHVKD . . FYAEDYGKLSRSCGNC TSTINGGGAFSAQ ...... DKVLQFNGRGTLNVND . . FYVQDYGKLVRNCGNC ESWIIGGGAYHAS ....... DKVVQHNGCGTVNIIN . . FYVEDYGKLYRSCGNC TANIIGGGAYHAS . . . . . DKVIQHNGCGHVNIVN . . FYANDYGKVYRSCGNC TMTIVGGI AHNAKDGYGGKPDKVLQHNSKNSTTVVKGNFTLTGEHGKLWRSCGDC TMTIVGGVAHNTTNGPGGKPDKVLQQNAKNSHTIVQGNFTLTGQHGKLWRSCGDC TVNI TGGAAYKAY . . . . . DKVFQMNASGTINIKN . . FRADDIGKLVRQNGGT TYQVIGGAGQGSP....... DKYFTQSGRGTTIIKN . . FCAEGKYGKVWCSCGNC VYNVNGGGAKNGE . . . . . DKVMQFDGKGTLYVNN . . . YYVDNYVRFCRSCGNC

Region IV

KD. NGGPRNVIVENSVAV . . . DGGVLCGINTNYGDTCKVINSCQ EG. NGG PRNINIKGVVAK . . NGGELCGVNHNYGDVCTITDSCQ S . KQCKRNVYIEGVTAK . . NGGELAG I NANYGDTATLKNVCA KGNTNCKRSVHMEGTTAV . . KGGELIGINTNYGDKATYSNNCY SN. NGGPRFLTVTSATVNG. . TIDSIAGVNRNYGDVATISGLKI TN . NGGPRNLTIISATVNG . . TIDSIAGVNRNFGDVAEIRDLRI S.. YAVNMTLDNSNISNVK . . DS IMRTDSSVSQGK ITNTRYSKV I D. QMPRSVQISNTKIQG. . PGLAI ISANSNYGDKISISGLTL G. . DQHQRHIVITNLTAVHGQAGQFVCGVNSNYQDTCTLHDIKM

Fig. 2. Multiple sequence alignment of the predicted partial MJ-PEL-1 (Meloidogyne javanica Pectate Lyase 1) protein sequence with partial protein sequences of fungal and bacterial Class III pectate lyases. Regions I to IV (black bars) indicate the conserved regions characteristic of Class III pectate lyases (PLs) (Shevchik et al. 1997). Very highly conserved charged residues are indicated by an asterisk (*), while number symbols (\#) indicate conserved cysteine residues. The boxed sequence indicates one of two putative glycosylation sites in MJ-PEL-1. Identical residues are highlighted in black, highly conserved residues are in gray. Only PLs with experimentally demonstrated activity were included in the alignment. The species of bacterium or fungi, the gene, and the accession number of the aligned sequences are: F_sol_PelA = Fusarium solani f. sp. pisi, PelA (M94692.1); F_sol_PelB = F. solani f. sp. pisi, PelB (U13051); F_sol_PelC = F. solani f. sp. pisi, PelC (U13049); F_sol_PelD = F. solani f. sp. pisi, PelD, (U13050); P_chr_Pel I = Pectobacterium chrysanthemi, PelI (Y13340); E_car_PelB = Erwinia carotovora, PelB (X79232); B_sub_PelA = Bacillus sp. BP-23, PelA (AJ237980); G_ros_Pel1 = Globodera rostochiensis, Pel-1 (AF127915); and MJ-PEL-1 = M. javanica pectate lyase 1 (AF455757). 
could not determine which gland or glands expressed $\mathrm{Mj}$-pel1 , because the basal cells of the three glands are closely packed together in early postinfection $\mathbf{J} 2$ nematodes (Bird and Saurer 1967) and there was not enough hybridization signal to determine where the gland connected to the esophageal lumen. No signal was observed in the negative control, the Mj-pel-1 sense probe (data not shown).

\section{Protein gel blotting and tissue localization of MJ-PEL-1 protein.}

Protein gel blotting was conducted to confirm the specificity of the anti-MJ-PEL-1 antibody. As illustrated in Figure 6A, several proteins are detected when Pichia-produced protein is incubated with the anti-MJ-PEL-1 antibody. These proteins correspond to the proteins produced during Pichia sp. expression (Fig. 3). MJ-PEL-1 also was treated with PNGase F to deglycosylate the protein. Figure $6 \mathrm{~A}$ illustrates a decrease in the observed molecular weight of the protein following deglycosylation; however, the deglycosylated protein still is detected by the anti-MJ-PEL-1 antibodies. A protein extract from preparasitic $\mathrm{J} 2$ nematodes also was included on the protein gel blot. In agreement with the hypothesis that $\mathrm{Mj}$-pel- $\mathrm{l}$ is a member of a small multigene family, two proteins were detected in the $\mathrm{J} 2$

Table 1. Nematode EST data mining ${ }^{\mathrm{a}}$

\begin{tabular}{ll}
\hline Species & Gene/EST $^{\mathbf{b}}$ \\
\hline Meloidogyne javanica-Mj-pel-1 & AF455757 \\
M. incognita-PelA & AW871541 (9) \\
M. incognita - PelD & AW828620 (2) \\
Heterodera glycines - PelA & BI748890(14) \\
Globodera rostochiensis - Pel-1 & AF127915 \\
\hline
\end{tabular}

${ }^{a}$ Expressed sequence tag (EST) databases were searched using TBLASTN (Altschul et al. 1997) with Mj-pel-1 (M. javanica Pectate Lyase 1) as a query sequence. The ESTs with significant similarity (Evalue $>2 \mathrm{e}-5$ ) were aligned using ClustalW (Jeanmougin et al. 1998) and then divided into contigs based on the alignment. Two contigs of ESTs were observed in $M$. incognita: one contig similar to PelA and the other similar to PelD from Fusarium solani f. sp. pisi. One contig of ESTs, most similar to PelA from Bacillus sp., also was observed for $H$. glycines. The G. rostochiensis Pel-1 gene also is listed. Each species name is followed by the gene name or the most similar gene in the case of the EST contigs.

${ }^{\mathrm{b}}$ The accession number for a representative gene or EST is listed for each group or contig, followed by the number of contig members in parentheses.

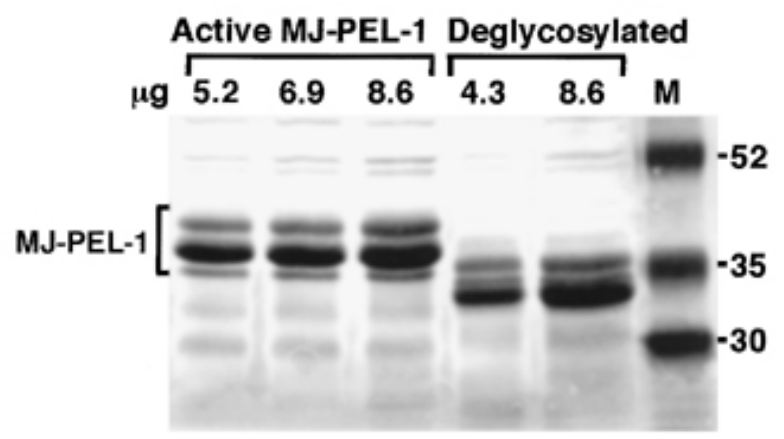

Fig. 3. Sodium dodecyl sulfate-polyacrylamide gel electrophoresis of active and deglycosylated MJ-PEL-1 (Meloidogyne javanica Pectate Lyase 1). The amount of protein in $\mu \mathrm{g}$ is shown above each lane. Active MJ-PEL-1 is loaded in the first three lanes. Active MJ-PEL-1 was treated with PNGase F; the resulting deglycosylated protein is loaded in lanes 4 and 5. Protein markers are in the lane labeled M; the molecular weight of the markers is shown in $\mathrm{kDa}$. extract. Two proteins approximately 33 to $34 \mathrm{kDa}$ in size are indicated with arrows in Figure 6A; the lower of these two proteins probably corresponds to MJ-PEL-1. The other smaller proteins present are detected nonspecifically by the secondary antibody and disappear when the titer of the secondary antibody is decreased (Fig. 6A). The proteins detected specifically in the $\mathrm{J} 2$ extract are closer in size to the deglycosylated form of Pichia-produced MJ-PEL-1 (Fig. 6A). This suggests that MJ-PEL-1 is not hyperglycosylated during secretion by the nematode.

To determine which esophageal glands accumulate MJ-PEL1 protein and to determine if the protein is secreted, we performed immunolocalizations. When anti-MJ-PEL-1 antibody was bound to paraffin sections of tomato roots that had been infected with nematodes for 2 days, the antibody specifically bound to the esophageal glands in the nematodes (Fig. 6C). We detected antibody binding in the basal cells of the esophageal glands and in the extension of these glands. The signal terminates at the metacorpus; therefore, MJ-PEL-1 is expressed in the subventral glands. In addition to the signal observed in the gland region, antibody binding also was observed on the exterior of nematode's head (Fig. 6C). The binding of the antiMJ-PEL-1 antibody to the exterior of the nematode confirms

Table 2. Biochemical characterization of MJ-PEL-1 activity ${ }^{\mathrm{a}}$

\begin{tabular}{lr}
\hline Sample & \multicolumn{1}{c}{ PL activity } \\
\hline MJ-PEL-1 + $\mathbf{C a}^{\mathbf{2 +}}$ & $\mathbf{1 . 4 6 4} \pm \mathbf{0 . 0 2 7}$ \\
MJ-PEL-1 + $\mathrm{Ca}^{2+}+$ EDTA & $-0.003 \pm 0.003$ \\
MJ-PEL-1 + $\mathbf{C a}^{2+}+$ EDTA $+\left[\mathbf{C a}^{2+}\right]$ & $\mathbf{1 . 3 1 1} \pm \mathbf{0 . 0 1 5}$ \\
MJ-PEL-1 + $\mathrm{Co}^{2+}$ & $0.005 \pm 0.005$ \\
MJ-PEL-1 + $\mathrm{Mg}^{2+}$ & $-0.004 \pm 0.005$ \\
MJ-PEL-1 + $\mathrm{Mn}^{2+}$ & $0.008 \pm 0.007$ \\
MJ-PEL-1 + Zn & $-0.188 \pm 0.028$ \\
No MJ-PEL-1 & $0.002 \pm 0.002$ \\
Pichia/BSA & $-0.021 \pm 0.003$ \\
Pichia extract & $-0.001 \pm 0.003$ \\
\hline
\end{tabular}

${ }^{a}$ Active MJ-PEL-1 (Meloidogyne javanica Pectate Lyase 1) (1.72 $\mu \mathrm{g}$ ) was mixed with pectate substrate and $\mathrm{CaCl}_{2}$ or other metal chloride salts. All metal salts were used at a final concentration of $1 \mathrm{mM}$.

${ }^{b}$ Pectate lyase (PL) activity is expressed as an increase in absorbance at 232 $\mathrm{nm}$ after $1 \mathrm{~h}$ at $30^{\circ} \mathrm{C}$. The values shown are the average and standard deviation for four replications. Controls include the standard $\mathrm{Ca}^{2+}$ assay with no MJ-PEL-1 added and similarly purified Pichia supernatants expressing either recombinant bovine serum albumin (BSA) or no recombinant proteins. The samples with PL activity are indicated in bold.

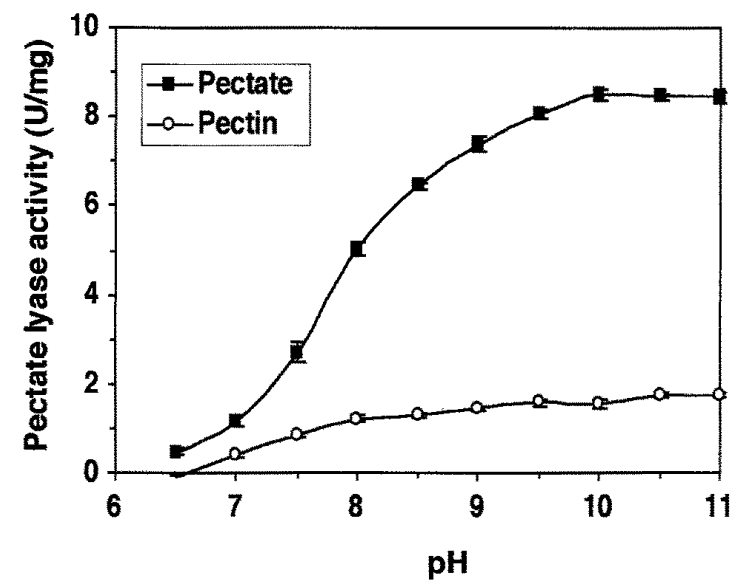

Fig. 4. Characterization of the $\mathrm{pH}$ dependence and substrate specificity of MJ-PEL-1 (Meloidogyne javanica Pectate Lyase 1). Activity of pectate lyase on pectate (polygalacturonic acid) or pectin at various $\mathrm{pH}$ values; activity is expressed per $\mathrm{mg}$ of total unpurified protein. Tris- $\mathrm{HCl}(50 \mathrm{mM})$ was used as a buffer at all $\mathrm{pH}$ levels, with a final $\mathrm{CaCl}_{2}$ concentration of $1 \mathrm{mM}$. 
the hypothesis that MJ-PEL-1 is secreted from the gland cell or cells into the plant extracellular matrix. No signal was observed in the negative control, the preimmune serum for the anti-MJ-PEL-1 antibody (data not shown).

\section{DISCUSSION}

The plant extracellular matrix is very complex. While composed primarily of cellulose, the rest of the matrix mainly consists of structural proteins and two other types of polysaccharides, hemicellulose and pectin (Alberts et al. 1994). The homogalacturan backbone of pectin varies in the degree of methylation. Pectins are cleaved by pectin lyases and are highly methylated and relatively hydrophobic (Mayans et al. 1997). Pectate, a demethylated form of pectin also known as polygalacturonic acid, is cleaved by pectate lyases and is highly charged (Mayans et al. 1997). Many groups of plant pathogens produce different types of pectinases that are classified by their substrates, type of lysis, and mode of action on the pectin polymer. Pectinases often are the first class of enzymes produced during infection (Alghisi and Favaron 1995). Pectin-degrading enzymes can include pectin methyl esterase, pectin acetyl esterase, pectate lyase, pectin lyase, and polygalacturonase. In bacterial pathogens such as Erwinia chrysanthemi, pectate lyases appear to be the major pectinolytic enzymes and play an important role in the maceration of plant tissues. In fungi like $F$. solani $\mathrm{f}$. sp. pisi, pectate lyases enable penetration of plants through degradation of the pectin in plant cell walls. Antibodies to these fungal pectate lyases inhibit pectate lyase activity (Guo et al. 1996) and prevent infection of the plant (Crawford and Kolattukudy 1987). Gene disruption experiments have confirmed that expression of pectate lyases at some level is essential for these fungi to cause plant disease (Rogers et al. 2000). Although a complex mixture of enzymes aids nematode penetration of the plant root, pectate lyases potentially play an important role.

Pectate lyases cleave the internal glycosidic bonds in pectate or the regions of pectins that are not highly methylesterified (Shevchik et al. 1997). The reaction proceeds by a $\beta$-elimination to yield oligomers that are 4,5-unsaturated at the nonreducing end (Herron et al. 2000). Pectate lyases can be divided into five major classes (Shevchik et al. 1997). Class I corresponds to the pectate lyase superfamily containing several well-described bacterial and plant proteins; this class includes PelA, PelB, PelC, PelD, and PelE of E. chrysanthemi. Class II corresponds to the periplasmic pectate lyases of $E$. carotovora and includes $\mathrm{KdgC}$ of $E$. chrysanthemi. Class III pectate lyases include PelB/Pel-3 from E. carotovora, the four Pels of $F$. solani f. sp. pisi, Pel-I of E. chrysanthemi, and Pel-1 from $G$. rostochiensis. Class IV includes PelL and PelX of E. chrysanthemi, while class V contains only PelZ of E. chrysanthemi (Shevchik et al. 1997).

MJ-PEL-1 is an additional example of a class III PL. Class III PLs are characterized by four conserved regions (Shevchik et al. 1997) (Fig. 2) and by the presence of several cysteine residues (Popeijus et al. 2000a). The identification of additional class III PLs has decreased the number of completely conserved cysteines to only two (Fig. 2, indicated with number symbols), but MJ-PEL-1 still has 12 cysteine residues in total. The large number of cysteine residues characteristic of class III pectate lyases may imply a rigid overall structure to the proteins. Based on sequence alignments, several strongly conserved amino acid residues with charged side chains are present in the four conserved regions: a lysine and an aspartate in region 2, a lysine in region 3 (substituted with an arginine in MJ-PEL-1), and a second aspartate in region 4. These strongly conserved or invariant residues may belong to the active site of the class III pectate lyases. In addition to the highly conserved charged residues, there are five completely conserved glycine residues: two found before conserved region I, two found between regions I and II, and one found in region III. The function of these conserved glycine residues remains unclear, but they may be involved in determining structure.

The biochemical characteristics of MJ-PEL-1 are similar to class III pectate lyases, but they are uniquely suited for the environment in which the protein is secreted. The root-knot nematode has a broad host range, and the $\mathrm{J} 2 \mathrm{~s}$ may encounter a range of different extracellular environments; the broad $\mathrm{pH}$ optimum of MJ-PEL-1 may provide extra flexibility. The high $\mathrm{pH}$ optimum of MJ-PEL-1 also may suggest that the esophageal gland secretions of the root-knot nematode are basic, requiring the en-

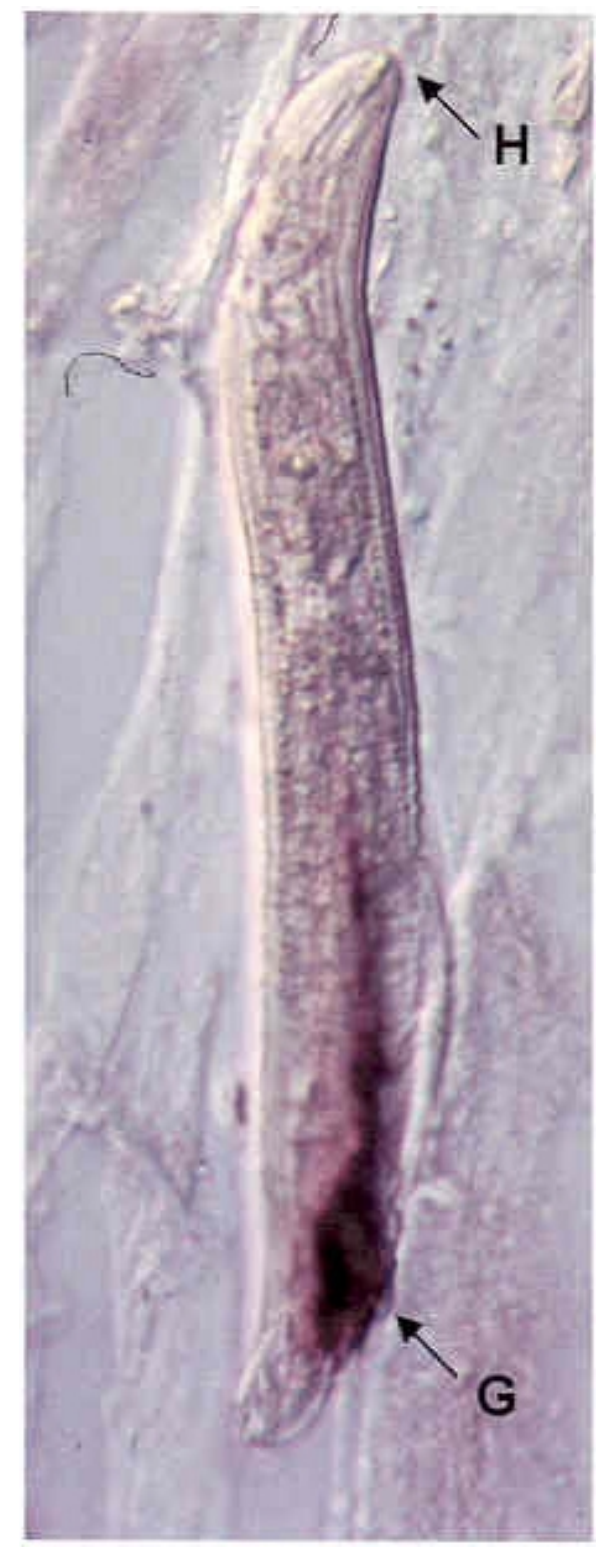

Fig. 5. RNA in situ hybridization of Mj-pel-1(Meloidogyne javanica Pectate Lyase 1) in postinfection second-stage juveniles (J2s). All sections were hybridized with antisense digoxigenin-labeled riboprobe followed by an alkaline phosphatase-conjugated antidigoxigenin antibody. Hybrids were detected by staining for alkaline phosphatase formation of a dark blue to black precipitate. In all sections, the postinfection $\mathrm{J} 2 \mathrm{~s}$ were in the tomato root for 3 days or less. The expression pattern indicates $\mathrm{Mj}$-pel-1 is expressed in an esophageal gland basal cell with some expression in the gland extension. The head and the gland of the nematode have been indicated with ' $\mathrm{H}$ ' and ' $\mathrm{G}$,' respectively. 
zyme to have a high $\mathrm{pH}$ optimum in order to be effective. Preliminary experiments have been conducted to evaluate the activity of MJ-PEL-1 on more complex substrates such as plant tissue. Incubation of cucumber mesocarp cylinders with MJ-PEL-1 results in the sloughing of cells and a net decrease in tissue mass (data not shown), suggesting that MJ-PEL-1 is able to digest plant tissue as well as purified pectate substrates.
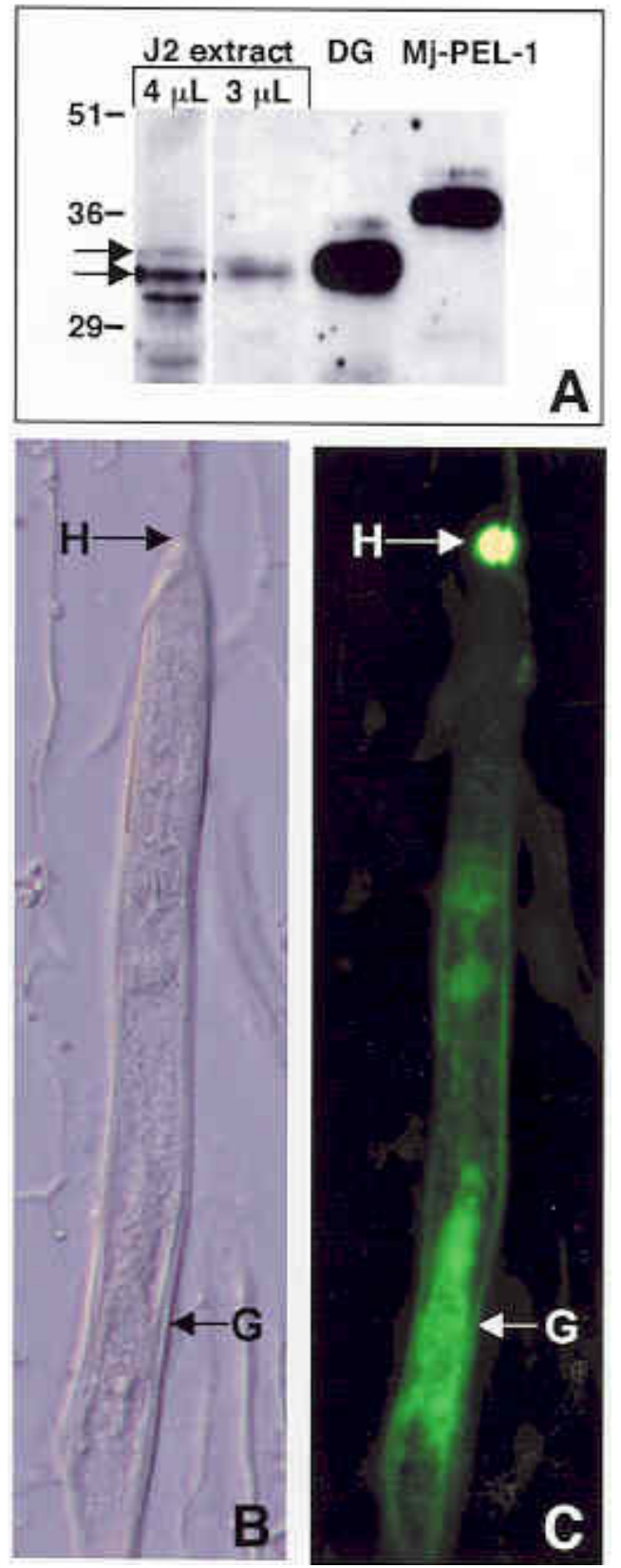

Fig. 6. Protein gel blot and immunolocalization of MJ-PEL-1 (Meloidogyne javanica Pectate Lyase 1). A, Preparasitic second-stage juvenile nematode protein extracts (J2), deglycosylated recombinant MJPEL-1 (DG), and recombinant MJ-PEL-1 (MJ-PEL-1) detected on a protein gel blot using a rabbit anti-MJ-PEL-1 antibody. The size of protein markers is indicated on the left side in $\mathrm{kDa}$. The secondary antibody was diluted 1:500,000 in the first $\mathrm{J} 2$ extract panel and 1:1,000,000 for the remaining lanes. Putative pectate lyases in $\mathrm{J} 2$ nematodes are indicated with arrows in the $\mathrm{J} 2$ extract lanes. $\mathbf{B}$ and $\mathbf{C}$, Immunolocalization of MJPEL-1 in a parasitic $\mathrm{J} 2$ nematode in a tomato root for 2 days. All sections were bound with the anti-MJ-PEL-1 antibody followed by an Oregon Green 488 goat anti-rabbit immunoglobulin $\mathrm{G}$ antibody; B, illustrates the differential interference contrast view, whereas $\mathbf{C}$, illustrates the immunofluorescence view. The head and the gland of the nematode have been indicated with ' $\mathrm{H}$ ' and ' $\mathrm{G}$,' respectively.
In situ hybridization experiments have localized the mRNA of $M j$-pel-1 to the basal cells of esophageal glands and immunolocalization experiments further pinpoint protein expression to the subventral glands. These results are consistent with data from other phytopathogenic nematodes; Pel-1 from G. rostochiensis and the cellulases from G. tabacum also localize to the subventral glands (Goellner et al. 2000; Popeijus et al. 2000a).

MJ-PEL-1 has a signal sequence and is predicted to be a secreted protein. Immunolocalization experiments confirm this hypothesis; the anti-MJ-PEL-1 antibody binds to the exterior of the nematode in the region of the stylet. MJ-PEL-1 is clearly secreted into the extracellular matrix of the plant, where its pectate lyase activity would help to depolymerize the pectin matrix and assist the nematode in its migration between the cells the host root. If MJ-PEL-1 is expressed in the later nematode developmental stages, it could be involved in maintaining giant cell plasticity. Future studies will demonstrate the timing of Mj-pel-1 gene expression as the nematode develops.

In summary, we have cloned and characterized a pectate lyase from the root-knot nematode $M$. javanica. MJ-PEL-1 is a class III PL with an absolute requirement for $\mathrm{Ca}^{2+}$ and a basic $\mathrm{pH}$ optimum. The transcript and the protein both localize to the basal cells of the subventral esophageal glands. The protein also is secreted and localizes to the exterior of the nematode. Accumulating evidence suggests a complex mixture of enzymes aids in nematode penetration of the host root; MJ-PEL1 potentially is a very important component. If protein-based inhibitors of MJ-PEL-1 can be developed, then it may be possible to express these inhibitors in plants to prevent nematode invasion and control these devastating pathogens.

\section{MATERIALS AND METHODS}

\section{Cloning of Mj-pel-1.}

Mj-pel-1 was cloned from a library enriched for esophageal gland genes. The gland library was constructed as previously described (Lambert et al. 1999) and putative gland genes were identified by differential hybridization. Using BLASTP (Altschul et al. 1997), one member of the library was identified as a putative pectate lyase and was designated $\mathrm{Mj}$-pel-1.

\section{Oligonucleotides.}

Genemed Synthesis (South San Francisco) synthesized all oligonucleotides: MjPL-Forward, 5'-TCACGACGTTGTAAAACGACGG-3'; MjPL-Reverse, 5'-TTCACACAGGAAACAGCTATG-3'; and MJPL-Eco, 5'-CGAATTCTGGCCTAAAGCAAGAAATA-3'.

\section{DNA sequence analysis.}

All cDNA clones were sequenced at the University of California Berkeley DNA sequencing facility. TBLASTN and BLASTP were used for sequence similarity searches (Altschul et al. 1997). PL protein sequences were aligned with CLUSTALW, version 1.8 (Jeanmougin et al. 1998).

\section{DNA gel blotting.}

Preparasitic J2 nematodes were collected from hydroponic nematode cultures (Lambert et al. 1992). Plant debris were removed by allowing the nematodes to crawl through six layers of Kimwipes as previously described (Ho et al. 1992). Packed nematodes were frozen in liquid nitrogen, then broken into small pieces using a tissue pulverizer (Fisher Scientific, Pittsburgh). The frozen nematode fragments were mixed with $1 \mathrm{ml}$ of proteinase $\mathrm{K}$ solution (0.1 M Tris- $\mathrm{HCl}$ [pH 8.0], $12.5 \mathrm{mM}$ EDTA, $0.15 \mathrm{M} \mathrm{LiCl}, 1 \% \mathrm{SDS}, 1 \mathrm{mM}$ dithiothreitol, and $2 \mathrm{mg}$ of proteinase $\mathrm{K}$ per $\mathrm{ml}$ ) and incubated at $37^{\circ} \mathrm{C}$ for $1 \mathrm{~h}$. The 
DNA was phenol/chloroform extracted and then precipitated with ethanol. The DNA was resuspended in $\mathrm{H}_{2} \mathrm{O}$. Nematode genomic DNA (5 $\mu \mathrm{g}$ per lane) was used on the DNA gel blot. Tomato genomic DNA was extracted from Lycopersicon esculentum Mill. UC82B using standard techniques (Dellaporta 1993; Dellaporta and Hicks 1983). DNA (10 $\mu$ g per lane) was used on the DNA gel blot.

The $M j$-pel-1 cDNA was amplified by polymerase chain reaction (PCR) from the original plasmid with oligonucleotides MjPL-Forward and MjPL-Reverse and purified with a Chroma Spin-200 column (Clontech, Palo Alto, CA, U.S.A.). The PCR product was labeled with ${ }^{32} \mathrm{P}-\mathrm{dCTP}$ using a Rediprime II kit (Amersham Pharmacia Biotech, Piscataway, NJ, U.S.A.); unincorporated nucleotides were removed using a QIAquick nucleotide removal kit (Qiagen, Valencia, CA, U.S.A.). The probe was hybridized to the filter and hybridization signals were detected by standard protocols (Sambrook et al. 1989). The blot was exposed to X-ray film for $24 \mathrm{~h}$ at $-80^{\circ} \mathrm{C}$ using one intensifying screen.

\section{Expression of recombinant protein.}

The Mj-pel-1 coding region minus the putative signal sequence was amplified from the original plasmid in pDIRECT (Lambert et al. 1999) using primers MjPL-Forward and MjPLEco at $94^{\circ} \mathrm{C}(30 \mathrm{~s}) ; 30$ cycles of $94^{\circ} \mathrm{C}(30 \mathrm{~s}), 55^{\circ} \mathrm{C}(30 \mathrm{~s})$, and $68^{\circ} \mathrm{C}(1 \mathrm{~min})$; and $68^{\circ} \mathrm{C}(10 \mathrm{~min})$. The resulting PCR product then was cloned into pCRII-Topo (Invitrogen, Carlsbad, CA, U.S.A.) and sequenced. The plasmid was digested with EcoRI and NotI and ligated into the vector pPICZ $\alpha$ A (Invitrogen). The resulting plasmid then was transformed into Pichia pastoris strain KM71 using electroporation. P. pastoris transformants were selected on YPD (1\% yeast extract, $2 \%$ peptone, $2 \%$ dextrose, and $2 \%$ agar) plates with $500 \mu \mathrm{g}$ of Zeocin per $\mathrm{ml}$. Selected transformants then were screened for expression of MJ-PEL-1. A line (designated MjPL-O) that expressed high levels of MJ-PEL-1 was selected for further analysis. MjPL-O was inoculated into $500 \mathrm{ml}$ of buffered minimal media with glycerol supplemented with 2 to $5 \mathrm{mM} \mathrm{CaCl}_{2}$ and grown for 2 days at $28^{\circ} \mathrm{C}$ with shaking. The cells then were harvested and induced in $150 \mathrm{ml}$ of minimal media containing methanol buffered using $100 \mathrm{mM}$ Tris- $\mathrm{HCl}, \mathrm{pH}$ 8.0, and supplemented with 2 to $5 \mathrm{mM} \mathrm{CaCl}$. To assay pectate lyase activity during protein expression, sodium pectate beads (Charkowski et al. 1998) in 100,000 Da molecular weight cut-off dialysis tubing (Fisher Scientific) were added in the induction phase. Pichia culture supernatant containing MJ-PEL-1 was harvested by centrifugation. The recombinant protein was concentrated by precipitating in 65 to $70 \%$ acetone and then was resuspended in $\mathrm{dH}_{2} \mathrm{O}$. Further analysis was conducted using concentrated protein.

\section{Pectate lyase assays.}

Solutions $(3 \%, \mathrm{wt} / \mathrm{vol})$ of pectin and pectate (polygalacturonic acid) substrates (Sigma-Aldrich, St. Louis) were prepared by boiling for $10 \mathrm{~min}$, followed by centrifugation for $10 \mathrm{~min}$ to remove any insoluble material. To determine the $\mathrm{pH}$ optimum, pectate lyase assays were conducted with 50 $\mathrm{mM}$ Tris- $\mathrm{HCl}$ at varying $\mathrm{pH}$, with $0.3 \%$ pectate, $1 \mathrm{mM}$ $\mathrm{CaCl}_{2}$, and $1.72 \mu \mathrm{g}$ of MJ-PEL-1. The change in absorbance at $232 \mathrm{~nm}$ was monitored over $1 \mathrm{~h}$ (Guo et al. 1996). Standard assays then were conducted in $50 \mathrm{mM}$ Tris- $\mathrm{HCl}, \mathrm{pH}$ 10.0 , with $0.3 \%$ pectate, $1 \mathrm{mM} \mathrm{CaCl}$, and $1.72 \mu \mathrm{g} \mathrm{MJ-PEL-1}$ (Guo et al. 1996). To determine substrate specificity, $0.3 \%$ pectin also was used as a substrate at varying $\mathrm{pH}$. To determine metal cofactor requirements, $\mathrm{CoCl}_{2}, \mathrm{MgCl}_{2}, \mathrm{MnCl}_{2}$, and $\mathrm{ZnCl}_{2}$ were substituted for $\mathrm{CaCl}_{2}$ at final concentrations of $1 \mathrm{mM}$.

\section{In situ hybridizations.}

The probe template was prepared by PCR amplification of the Mj-pel-1 plasmid with 10 pmol each of MjPL-Forward and MjPL-Reverse primers as described above. The cDNA insert was purified with a Chroma Spin-200 column. Digoxigenin-labeled RNA probes were synthesized from $300 \mathrm{ng}$ of purified template with the T7 and T3 AmpliScribe High Yield Transcription Kits (Epicentre Technologies, Madison, WI, U.S.A.) with the following nucleotide concentrations: $7.5 \mathrm{mM}$ GTP, $7.5 \mathrm{mM}$ ATP, $7.5 \mathrm{mM}$ CTP, $5 \mathrm{mM}$ UTP, and $3 \mathrm{mM}$ dig-11-UTP (Roche Molecular Biochemicals, Indianapolis, IN, U.S.A.). Labeled RNA was purified with a Chroma Spin-200 column. The RNA probe was hydrolyzed to a length of approximately 150 to 300 bases (Ruzin 1999), then used at a concentration of $1 \mathrm{ng}$ per $\mu \mathrm{l}$.

Excised nematode-infected root tips were fixed in FAA (3.7\% formaldehyde, $50 \%$ ethanol, $5 \%$ glacial acetic acid), were paraffin embedded (Schichnes et al. 1999), and were cut to $10-\mu \mathrm{m}$ sections on a rotary microtome. The sections were processed and hybridized to the $M j$-pel- 1 riboprobes according to published protocols (Jackson 1992). Hybridized probe was detected as previously described (Ruzin 1999). Labeled cells were examined with a Zeiss Axioskop 2 microscope, and images were captured with a Zeiss Axiocam.

\section{Protein gel blotting and immunolocalizations.}

To prepare a nematode protein extract, preparasitic J2 nematodes were collected and pulverized as described above. The frozen nematode fragments were mixed with 0.3 to $0.4 \mathrm{ml}$ of SDS-PAGE sample buffer $(0.125 \mathrm{M}$ Tris-HCl, $\mathrm{pH} 6.8,2 \% 2-$ mercaptoethanol, $4 \%$ SDS, $20 \%$ glycerol, $0.001 \%$ bromphenol blue) and vortexed to extract the proteins. In all, 3 and $4 \mu$ of the nematode $\mathrm{J} 2$ extract, $10 \mathrm{ng}$ of recombinant MJ-PEL-1, and $10 \mathrm{ng}$ of deglycosylated recombinant MJ-PEL-1 were subjected to SDS-PAGE using standard techniques (Ausubel et al. 1992). The protein gel then was transferred overnight at $10 \mathrm{~V}$ to polyvinylidene difluoride membrane (Millipore, Bedford, MA, U.S.A.) in 10\% ethanol, 10 mM CAPS, pH 11.0 (United States Biochemical, Cleveland, OH, U.S.A.). The membrane was blocked in $0.1 \%$ BSA and then incubated with a commercially prepared rabbit anti-MJ-PEL-1 antibody diluted 1:10,000 (Covance Research Products, Denver, PA, U.S.A.). The antibody was affinity purified using the AminoLink Plus Immobilization Kit and ImmunoPure Gentle $\mathrm{Ag} / \mathrm{Ab}$ buffers (Pierce Chemical Company, Rockford, IL, U.S.A.) according to the manufacturer's instructions. The anti-rabbit-horseradish peroxidase conjugated secondary antibody (Sigma-Aldrich) was diluted 1:500,000 (Fig. 6, first lane of J2 extract) or 1:1,000,000 (all remaining lanes). The membranes were developed using SuperSignal West Femto Chemiluminescent Substrate (Pierce Chemical Company) according to the manufacturer's instruction. Panels from two separate protein gel blots were included to better illustrate the second putative pectate lyase band.

To prepare for immunolocalizations, excised nematode-infected tomato root tips were fixed in AA (50\% ethanol, 5\% glacial acetic acid), paraffin embedded, and sectioned as described above. The slides were treated with xylene to remove the paraffin, followed by a 1-min incubation in cold acetone. The tissue then was rehydrated as previously described (Ruzin 1999). After treating with Proteinase $\mathrm{K}$ at $4 \mu \mathrm{g} / \mathrm{ml}$ for $45 \mathrm{~min}$, the tissue was fixed in $4 \%$ formalin. The slides were blocked in $1 \%$ goat serum and then incubated at room temperature for $3 \mathrm{~h}$ with unpurified anti-MJ-PEL-1 antibody diluted 500-fold. After washing, the slides were incubated for $3 \mathrm{~h}$ at room temperature with Oregon Green 488 goat anti-rabbit immunoglobulin G antibody (Molecular Probes, Eugene, OR, U.S.A.) 
diluted 1:250. Labeled cells were examined with a Zeiss Axioskop 2 microscope with a fluorescent light source and images were captured with a Zeiss Axiocam.

\section{ACKNOWLEDGMENTS}

We thank S. Bekal and J. Painter for their critical review of the manuscript. This work was supported by grant number 99-35302-8692 from the United States Department of Agriculture National Research Initiative Competitive Grants Program.

\section{LITERATURE CITED}

Alberts, B., Bray, D., Lewis, J., Raff, M., Roberts, K., and Watson, J. D. 1994. Pages 1137-1150 in: Molecular Biology of the Cell. Garland Publishing, New York.

Alghisi, P., and Favaron, F. 1995. Pectin-degrading enzymes and plantparasite interactions. Eur. J. Plant Pathol. 101:365-375.

Altschul, S. F., Madden, T. L., Schaffer, A. A., Zhang, J., Zhang, Z., Miller, W., and Lipman, D. 1997. Gapped BLAST and PSI-BLAST: A new generation of protein database search programs. Nucleic Acids Res. 25:3389-3402.

Ausubel, F. M., Brent, R., Kingston, R. E., Moore, D. D., Seidman, J. G., Smith, J. A., and Struhl, K.1992. Pages 10-1 to 10-35 in: Short Protocols in Molecular Biology. 2nd ed. John Wiley and Sons, New York.

Barras, F., Gijsegem, F. V., and Chatterjee, A. K. 1994. Extracellular enzymes and pathogenesis of soft-rot Erwinia. Annu. Rev. Phytopathol. 32:201-234.

Bird, A. F., Downton, W. S. J., and Hawker, J. S. 1974. Cellulase secretion by a second stage larvae of the root-knot nematode (Meloidogyne javanica). Marcellia 38:165-169.

Bird, A. F., and Saurer, W. 1967. Changes associated with parasitism in nematodes. II. Histochemical and microspectrophotometric analyses of preparasitic and parasitic larvae of Meloidogyne javanica. J. Parasitol. 53:1262-1269.

Charkowski, A. O., Alfano, J. R., Preston, G., Yuan, J., He, S. Y., and Collmer, A. 1998. The Pseudomonas syringae pv. tomato HrpW protein has domains similar to harpins and pectate lyases and can elicit the plant hypersensitive response and bind to pectate. J. Bacteriol. 180:5211-5217

Crawford, M. S., and Kolattukudy, P. E. 1987. Pectate lyase from Fusarium solani f. sp pisi: Purification, characterization, in vitro translation of the mRNA, and involvement in pathogenicity. Arch. Biochem. Biophys. 258:196-205.

Dellaporta, S. L. 1993. Plant DNA miniprep and microprep version 2.12.3. Pages 522-525 in: The Maize Handbook. M. Freeling, V. Walbot, eds. Springer-Verlag, New York.

Dellaporta, S. L., and Hicks, J. B. 1983. A plant DNA minipreparation: Version II. Plant Mol. Biol. Rep. 1:19-20.

Ding, X., Shields, J., Allen, R., and Hussey, R. S. 1998. A secretory cellulose-binding protein cDNA cloned from the root-knot nematode (Meloidogyne incognita). Mol. Plant-Microbe Interact. 11:952-959.

Dropkin, V. H. 1963. Cellulase in phytoparasitic nematodes. Nematologica 9:444-454.

Gao, B., Allen, R., Maier, T., Davis, E. L., Baum, T. J., and Hussey, R. S. 2001. Identification of putative parasitism genes expressed in the esophageal gland cells of the soybean cyst nematode Heterodera glycines. Mol. Plant-Microbe Interact. 14:1247-1254.

Goellner, M., Smant, G., De Boer, J. M., Baum, T. J., and Davis, E. L. 2000. Isolation of beta-1,4-endoglucanase genes from Globodera tabacum and their expression during parasitism. J. Nematol. 32:154-165.

Guo, W., Gonzalez-Candelas, L., and Kolattukudy, P. E. 1996. Identification of a novel pelD gene expressed uniquely in planta by Fusarium solani f. sp. pisi (Nectria haematococca, mating type VI) and characterization of its protein product as an endo-pectate lyase. Arch. Biochem. Biophys. 332:305-312.

Herron, S. R., Benen, J. A. E., Scavetta, R. D., Visser, J., and Jurnak, F. 2000. Structure and function of pectic enzymes: Virulence factors of plant pathogens. Proc. Natl. Acad. Sci. U.S.A. 97:8762-8769.

Ho, J.-Y., Weide, R., Ma, H. M., Wordragen, M. F., Lambert, K. N., Koornneef, M., Zabel, P., and Williamson, V. M. 1992. The root-knot nematode resistance gene (Mi) in tomato: Construction of a molecular linkage map and identification of dominant cDNA markers in resistant genotypes. Plant J. 2:971-982.

Hofmann K., Bucher P., Falquet L., and Bairoch A. 1999. The PROSITE database, its status in 1999. Nucleic Acids Res. 27:215-219.

Hugouvieux-Cotte-Pattat, N., Condemine, G., Nasser, W., and Reverchon, S. 1996. Regulation of pectinolysis in Erwinia chrysanthemi. Annu. Rev. Microbiol. 50:213-257.

Jackson, D. 1992. In situ hybridization in plants. Pages 163-174 in: Molecular Plant Pathology: A Practical Approach. S. J. Gurr, M McPherson, and D. J. Bowles, eds. IRL Press, Oxford.

Jeanmougin, F., Thompson, J. D., Gouy, M., Higgins, D. G., and Gibson, T. J. 1998 Multiple sequence alignment with Clustal X. Trends Biochem. Sci. 23:403-5.

Lambert, K. N., Allen, K. D., and Sussex, I. M. 1999. Cloning and characterization of an esophageal-gland-specific chorismate mutase from the phytopathogenic nematode Meloidogyne javanica. Mol. Plant-Microbe Interact. 12:328-336.

Lambert, K. N., Tedford, E. C., Caswell, E. P., and Williamson, V. M. 1992. A system for continuous production of root-knot nematode juveniles in hydroponic culture. Phytopathology 82:512-515.

Mayans, O., Scott, M., Connerton, I., Gravesen, T., Benen, J., Visser, J. Pikersgill, R., and Jenkins, J. 1997. Two crystal structures of pectin lyase A from Aspergillus reveal a $\mathrm{pH}$ driven conformational change and striking divergence in the substrate-binding clefts of pectin and pectate lyases. Structure 5:677-689.

McCarter, J., Abad, P., Jones, J. T., and Bird, D. 2000a. Rapid gene discovery in plant parasitic nematodes via expressed sequence tags. Nematology 2:719-731.

McCarter, J. P., Bird, D. McK., Clifton, S. W., and Waterson, R. H. 2000b. Nematode gene sequences, December 2000 update. J. Nematol. 32:331333.

Nakai, K., and Kanehisa, M. 1992. A knowledge base for predicting protein localization sites in eukaryotic cells. Genomics 14:897-911.

Popeijus, H., Overmars, H., Jones, J., Blok, V., and Goverse, A. 2000a. Degradation of plant cell walls by a nematode. Nature 406:36-37.

Popeijus, M., Blok, V. C., Cardle, L., Bakker, E., Phillips, M. S., Helder, J., Smant, G., and Jones, J. T. 2000b. Analysis of genes expressed in second stage juveniles of the potato cyst nematodes Globodera rostochiensis and G. pallida using the expressed sequence tag approach. Nematology 2:567-574.

Rogers, L. M., Kim, Y.-K., Guo, W., Gonzalez-Candelas, L., Li, D., and Kolattukudy, P. 2000. Requirement for either a host- or pectin-induced pectate lyase for infection of Pisum sativum by Nectria hematococca. Proc. Natl. Acad. Sci. U.S.A. 97:9813-9818.

Romanos, M. A., Scorer, C. A., and Clare, J. J. 1992. Foreign gene expression in yeast: A review. Yeast 8:423-488.

Rosso, M.-N., Favery, B., Piotte, C., Arthaud, L., De Boer, J. M., Hussey, R. S., Bakker, J., Baum, T. J., and Abad, P. 1999. Isolation of a cDNA encoding a beta-1,4-endoglucanase in the root-knot nematode Meloidogyne incognita and expression analysis during plant parasitism. Mol. Plant-Microbe Interact. 12:585-591.

Ruzin, S. E. 1999. Pages 193-203 in: Plant Microtechnique and Microscopy. Oxford University Press, Oxford.

Sambrook, J., Fritsch, E. F., and Maniatis, T. A. 1989. Pages 9.31-9.57 in: Molecular Cloning: A Laboratory Manual. 2nd ed. Cold Spring Harbor Laboratory Press, Cold Spring Harbor, NY, U.S.A.

Sasser, J. N. 1980. Root-knot nematodes: A global menace to crop production. Plant Dis. 64:36-41.

Schichnes, D., Nemson, J., Sohlberg, L., and Ruzin, S. E. 1999. Microwave protocols for paraffin microtechnique and in situ localization in plants. Microsc. Microanal. 4:491-496.

Shevchik, V., Robert-Baudouy, J., and Hugouviux-Cotte-Pattat, N. 1997. Pectate lyase PelI of Erwinia chrysanthemi 3937 belongs to a new family. J. Bacteriol. 179:7321-7330.

Smant, G., Stokkermans, J., Yan, Y., De Boer, J. M., Baum, T. J., Wang, X., Hussey, R. S., Davis, E. L., Gommers, F. J., Henrissat, B., Helder, J., Schots, A., and Bakker, J. 1998. Endogenous cellulases in animals: Cloning of expressed beta-1,4-endoglucanase genes from two species of plant-parasitic cyst nematodes. Proc. Natl. Acad. Sci. U.S.A. 95:4906-4911.

Vozza, L. A., Wittwer, L., Higgins, D. R., Purcell, T. J, and Bergseid, M. 1996. Production of a recombinant bovine enterokinase catalytic subunit in the methylotrophic yeast Pichia pastoris. Bio/Technology 14:77-81.

Wang, X., Allen, R., Ding, X., Goellner, M., Maier, T., De Boer, J. M., Baum, T. J., Hussey, R. S., and Davis, E. L. 2001. Signal peptide-selection of cDNA cloned directly from the esophageal gland cells of the soybean cyst nematode Heterodera glycines. Mol. Plant-Microbe Interact. 14:536-544

Williamson, V. M., and Hussey, R. S. 1996. Nematode pathogenesis and resistance in plants. Plant Cell 8:1735-1745. 